\title{
1. Overall assessments and balancing of interests
}

\subsection{INTRODUCTION}

The Swedish Academy Glossary (SAOL) does not list a definition for the term 'overall assessment'. However, the term 'overall assessment' refers to a number of factors, aspects or perspectives that are brought together into a comprehensive assessment, an overall assessment. In this book, the word has a more specific meaning. An overall assessment means that a choice must be made between several possible decision options using certain criteria in order to achieve one or more objectives. This definition addresses both the meaning and the purpose of an overall assessment.

Virtually everyone makes overall assessments on a daily basis. This might involve big, important things like purchasing a home: What is our price range? What city/neighbourhood? Running costs (taxes, maintenance, utilities)? Proximity to daycare, school and work? Renovation needs? And so on. Or the assessment might involve where the family should go on holiday. There are a few options (e.g., Spain, Bulgaria or Italy) and a number of selection criteria such as cost, climate and how child-friendly it is. Another example is buying a new car, which will be explored in detail later on. Even in such cases, there are several different options to consider when evaluating the different car models, which have different prices, different environmental performance, different collision safety and comfort levels, and so on.

All overall assessments in this book involve making a decision according to the definition given in the introduction. This also applies for overall assessments made in a legal context. The structured method for overall assessments that will be presented can thus be used in all types of overall assessments, whether these involve buying a house, a holiday or a car, or, for example, assessing if a clause in a contract is 'unreasonable'. In addition, it does not matter which area of law the overall assessment concerns.

Balancing of interests also involves multiple options, criteria and objectives. One important issue that will be examined is if there is any difference between overall assessments and balancing of interests, and if so, what that difference may be. 
Legal overall assessments and balancing of interests have great significance for the parties involved and for society at large. Typical examples of such assessments and balancing will be provided later in this chapter. This may involve, for example, the use of land and water, whether an agreement should be nullified, whether camera surveillance should be permitted, what is consistent with 'the best interests of the child' in a custody dispute or on the use of an optional rule in the Swedish Code of Judicial Procedure (hereinafter 'RB'). The decision may concern very large sums of money or an individual's future. Erroneous decisions can furthermore cause major damage - economically, socially and materially. Decisions must therefore be carefully and thoroughly considered. They must also, in every instance involving the exercise of power, be transparent and people affected must have been given an opportunity to participate in the decision-making process. Complicated decisions that require an overall assessment are, however, often informal in the sense that the decision-maker simplifies by not carefully investigating different options, criteria and objectives, either because this takes time and may be costly, or because structured models for decision-making seem difficult to grasp or implement. Instead, shortcuts are taken, which in the literature of the field are often called heuristics. ${ }^{1}$

The structured analysis for decision-making in overall assessments and balancing of interests that will be discussed in Chapter 2 is referred to in this book as multi-criteria analysis, hereinafter referred to by its acronym MCA. This concept is also often referred to as multiple-criteria decision analysis (MCDA). The designation for the methods used in this analysis is multi-criteria decision methods (MCDM). In addition, a distinction is usually made between multi-objective decision models (MODM) and multi-attribute decision models (MADM), which are umbrella terms that encompasses many models. The first of these is used in the planning process that precedes a decision. MADM is used when there are fixed options and formulated criteria for the decision to be made. The basic model described in Chapter 2 includes both. A distinction is furthermore made in MCA between multi-attribute value theory (MAVT) and multi-attribute utility theory (MAUT). The difference between them is that MAVT presupposes that the decision criteria and the outcomes are certain, while MAUT is a model that also handles uncertainty. ${ }^{2}$

For a discussion on shortened decision paths, see Chapter 3.

2 About the aforesaid, see Paul Goodwin and George Wright, Decision Analysis for Management Judgment (Wiley, 4th edn, 2012) 34, JS Dodgson and others, 'Multi-criteria Analysis: A Manual' < http://eprints.lse.ac.uk/12761/1/ Multi-criteria_Analysis.pdf> 50 (retrieved 15 July 2016), also see Valerie Belton 
Unlike MAVT, MAUT does not impose a requirement for independence on the criteria. However, it is rather complicated to use. The simple additive model, simple additive weighting (SAW), which is an MADM method, will therefore be used in this book, but simple multi-attribute rating technique (SMART) will also be described. Some uncertainty can be taken into account in these methods, for example by giving criteria less weight in the sensitivity analysis or by assessing uncertainty when selecting options. ${ }^{3}$ Another alternative is to add a probability assessment afterwards. The results from the MCA analysis can then be multiplied by the probability of an option occurring. ${ }^{4}$ In this way, probability can rather easily be taken into account even when using the additive model. Uncertainty can furthermore be handled with fuzzy logic, which can be combined with MCA. Fuzzy logic, which primarily belongs to the scientific fields of philosophy, mathematics and technology, is used for things like computer programming and the control and regulation of machines. Fuzzy logic is based on set theory and on the premise that language is vague. Water can, for example, be described as 'warm', 'lukewarm' or 'cool', but there is no way to put a precise linguistic label on these states or the transitions between them. When, for example, does 'lukewarm' become 'warm' and how to describe this in words? Fuzzy logic seems to fit well into a legal context because legal language is often vague. The basics of fuzzy logic will be introduced and applied in Chapter 4. Fuzzy logic will also be applied in Chapter 6 .

The abbreviation MCA, which is used consistently throughout this book in lieu of the terms MCDA and MCDM, is an umbrella term for a large number of different techniques and models which are used,

and Theodor Stewart, Multiple Criteria Analysis. An Integrated Approach (Kluwer 2002) 119ff and Freerk A Lootsma, Multi-Criteria Analysis via Ratio and Difference Judgement (Kluwer Academic Publisher, 1999) 15ff. Easily approachable literature on the fundamentals of MCA is also available on the Internet. See e.g., Dodgson and others, mentioned above, to which references are made in this book; Vicky Mabin and Michael Beattie, A Practical Guide to Multi-Criteria Decision Analysis <http://www.victoria.ac.nz/som/researchprojects/publications/ Multi-Criteria_Decision_Analysis.pdf> (retrieved 5 July 2016) and GA Mendoza, P Macan and others, Guidelines for Applying Multi-Criteria Analysis to the Assessment of Criteria and Indicators (1999, The Criteria and Toolbox series, Center for International Forestry Research) < http://www.cifor.org/livesinforests/ publications/pdf_files/toolbox-9c.pdf $>$ (accessed 22 July 2016).

3 See section 2.3.8, below.

4 Jacek Malczewski, GIS and Multicriteria Decision Analysis (Wiley 1999) 214, Ralf L Keeny and Howard Raiffa, Decisions with Multiple Objectives: Preference and Value Tradeoffs (Cambridge University Press 1993) 219ff. 
for example, in large-scale projects such as the construction of airports, roads, power plants and, not least, in land and environmental planning. When, for example, an airport is to be built, a multitude of factors must be taken into account, such as noise, emissions, safety, and transport routes to and from the airport. In the end, a great number of circumstances must be analysed, considered and weighed before a decision can be made on where the airport will be located. A large-scale project can include such an enormous number of factors that an intuitive overall assessment becomes impossible. Instead, a structured decision model is required, experts must be consulted, and computer support used.

As will be discussed in Chapter 2, two MCA models that have been used for a long time and found to be robust, namely SMART and SAW - which are additive, part of the MAVT family and have the same basic structure can present difficulties when used in a legal context as direct decision tools. They can, however, be used as analytical tools to structure the decision material and for tentative decision support. It is also possible in a legal context to mathematically combine numeric scoring and weighing. However, it is important to be careful with the results and match these against intuition. ${ }^{5}$ Of course, MCA must be adapted to a legal context. This adaptation poses some difficulties, yet also provides relief in other respects. Attempting to make this adaptation has been a key objective in this book.

Deciding on a legal dispute that requires an overall assessment or a balancing of interests is usually easier than determining where an airport should be located - or in any case different. This is true even for complicated disputes with a number of factors to take into consideration. A legitimate question is therefore whether a structured decision model is really needed for legal decision-making. Would it not be just as well to weigh different factors intuitively? Another partially related question is whether a structured decision model - intended primarily for large projects - should be used in legal decision-making. Intuition, which will be briefly discussed in Chapter 3, is both good and necessary. Intuition does not, however, provide transparency, is not structured and is insufficient when the decision basis is too expansive. The other question and possible concern - that MCA might be inappropriate to use in a legal context - is more complicated. As already mentioned, MCA could be used as soon as there is a

5 Cf Andy Stirling and Sue Meyer, Rethinking Risk: A Pilot Multi-criteria Mapping of a Genetically Modified Crop in Agricultural Systems in the UK $<\mathrm{http}: / /$ users.sussex.ac.uk/ prfh0/Rethinking\%20Risk.pdf $>$ (1999) (retrieved 1 July 2016). Also see section 3.5 below. 
situation with several possible decision options, criteria and goals. When MCA is used for large projects involving, for example, infrastructure or the planning of other public activities, most of the data used is measurable in some way (costs, quantities, distance, volume of different types of emissions, and so on). ${ }^{6}$ In practice, however, MAVT and the additive model are also used on factors that can only be assessed subjectively.

In legal assessments, the criteria for decision-making are rarely measurable. The importance of individual legal facts (criteria) is mainly assessed subjectively. 'Importance' here refers to both the strength and the relevance of concrete legal facts as well as their relative weight. In overall assessments and balancing of interests in particular, different relevant and concrete legal facts are not equally important - some carry more weight than the others. This is true also with respect to evidentiary facts, that is, the value of a piece of evidence, which are usually not measurable but are instead assessed subjectively. In addition, the evidentiary value of different evidentiary facts varies. Even though the evidentiary value of an individual evidentiary fact is generally not objectively measurable but is instead decided intuitively, some legal doctrine recommends the use of mathematical methods for the evaluation of evidence. Thus, there are already structured methods for the evaluation of evidence, such as the evidentiary value method and the evidentiary theme method. ${ }^{7}$ MCA, such as it is used in this book, can therefore for questions of law be seen as a counterpart to these methods for evaluation of evidence.

Because the importance of concrete legal facts in overall assessments and balancing of interests is assessed subjectively, the results of the analysis naturally become more uncertain than if there had been measurable data. ${ }^{8}$ MCA can nevertheless provide valuable decision support, particularly as there are often many factors to take into account in overall assessments and balancing of interests. In any case, using MCA the decision-makers must make a thorough analysis of each individual factor, thus it explicitly forces them to take a position on what they consider important or less important. Presumably, this then leads to a better decision than if

6 See e.g., Multikriterieanalyser vid prioriteringar inom hälso-och sjukvården - kriterier och analysmetoder. Linköpings universitet, Prioriteringscentrum (2013:2) and Multikriterieanalys för hållbar efterbehandling: Metodutveckling och exempel på tillämpning. (Swedish Environmental Protection Agency (2009) Report 5891).

7 Section 6.1.1, below.

8 Dodgson and others (n 2) 27, 124. The problem with subjective assessments is lessened if the decision-maker is a professional, for example a judge who makes decisions on a daily basis. 
everything had been assessed intuitively. The above question on whether it is appropriate to use MCA in a legal context can thus be answered in the affirmative. This is true even if the method will be used only to structure and analyse the decision basis and the decision-maker does not want to set numeric values on different criteria and put the effort into conducting a comprehensive mathematical MCA analysis.

How MCA can be applied to overall assessments of legal issues is discussed in Chapter 4. The examples are illustrated with graphic figures in order to show the different stages in MCA and the simple additive model. The premise in the examples is that there are no uncertainties with respect to evidentiary issues (questions of facts), that is, the facts are not uncertain. Consequently, the overall assessments that are made in this chapter concern the legal significance and weight of several different concrete legal facts in the case which together give, or may give, rise to a legal consequence - or at least could be argued to do so (questions of law).

In Chapter 5, certain evidentiary issues with respect to prognostic assessments in law are discussed from the perspective of utility theory, which is integrated into MAUT. There is a clear difference between the entertainment of evidentiary questions in law and according to the utility theory. In law, disputed facts are usually handled separately in the way that legal consequences are attached to facts that have been proven in accordance with the applicable standard of proof. Utility theory, on the other hand, merges probability and utility into an integrated value. This chapter discusses and demonstrates how utility can and should be taken into account in a legal context when the law stipulates prognostic assessments.

The sixth and final chapter of the book provides a short summary of the evidentiary law theories - the evidentiary value method and the evidentiary theme method - which have been the focus of the law of evidence debate in Sweden and Scandinavia in recent decades. This description provides a framework for understanding the subsequent sections in the chapter on different aspects of evidence evaluation and the use of MCA and fuzzy logic in the assessment of oral testimonies and on the burden of proof and standard of proof.

\subsubsection{Is MCA a Legal Method?}

The question of what constitutes a legal method is controversial. A broad definition is that every method used to solve legal problems is a legal method. In this case, MCA is a legal method if it is used for this purpose. Legal method is, however, usually and traditionally associated with different ways of deciding on the meaning of a rule of law, that is, with interpretation and application of law. For example, the German legal philosopher 
Philipp Heck advocated a method proposing that all application of law is the result of balancing of interests. Yet, Heck's methodology, which came to be called the jurisprudence of interests ('Interessenjurisprudenz'), deals with an entirely different sort of balancing of interests than that discussed in this book. Heck argues that it is not possible to determine the contents of a legislative rule based solely on the aim or purpose of the law. The law is instead the result of a tug of war between different factors and can therefore only be understood as effects of a conflict of interest:

Es ist nicht möglich, den Inhalt einer Gesetzenorm nur aus ihrem Zweck zu erklären. Das Gesetz ist, wie jede Handlung, die Resultante, gleichsam die Kraftdiagonalen ringender Faktoren, deren Wirkung wir nur als Interessenkonflikt erfassen können. ${ }^{9}$

Teleological interpretation, which was criticized by Heck, is another well-known method that can be used to determine the meaning of a legislative rule. ${ }^{10}$

Both MCA and law application methods are normative. The aim of MCA is to help the decision-maker make the 'best' decision possible. The aim of a law application method is also to help the decision-maker (the legal decision-maker) make the 'best' ruling possible. However, no attempt is made in this book to fit MCA into a law application method, since the methods for the application of law and for decision-making under MCA have different starting points. Regarding, for example, the teleological method, as presented by Ekelöf, the goal of this is to achieve morality and behaviour modification and, from these starting points, make the 'best' decision possible. ${ }^{11}$ Even with this objective it is quite appropriate to use MCA, which does not have the aim of indicating from which values individual legal facts in a case should be assessed. The purpose of MCA is instead to provide a structured analysis and decision model. What values the individual decision-maker then wants to insert into the model depends on what he or she considers important and what will lead to a 'good' decision. The scoring and weighting of criteria with regard to the different

9 Philipp Heck, Das Problem der Rechtsgewinnung. Gesetzeauslegung und Interessenjurisprudens: Begriffsbildung und Interessenjurisprudenz. Redigert von Roland Dubischer (Verlag Gehlen 1968) 55.

10 Cf $\mathrm{n} 11$ below and Per Olof Ekelöf and Henrik Edelstam, Rättegång: Första häftet (8th edn, Norstedts Juridik 2002) 80. Also see Per Henrik Lindblom, Miljöprocess, Del 1 (Iustus 2001) 81, footnote 20.

11 Per Olof Ekelöf, Teleological Construction of Statutes (1958) 2 Scandinavian Studies in Law 75. Professor Ekelöf († 1990) was a prominent professor of procedural law at the Faculty of Law at Uppsala University. 
decision options is, however, done in accordance with legal requirements. If, for example, a rule of law is to be interpreted restrictively, this may affect the scoring and weighting. If it instead is interpreted broadly, this may correspondingly affect how individual legal facts are assessed. MCA is thus not a law application method, but rather a method that belongs to another science - decision theory. It can be equated with other auxiliary sciences of law, such as semantics or witness psychology.

Concerning the use of MCA as a legal analytical tool, the method can be used in every assessment in which a number of circumstances have been or will be aggregated in a total appraisal. The method therefore has a very broad range of applications. However, while the volume of literature in its own field of knowledge is extensive, there is very little written in legal literature about MCA and fuzzy logic. Even rarer is legal literature in which, as in this book, the method is actually applied.

MCA can be used as an instrument for the planning of negotiations, both before and after a legal dispute has arisen. Howard Raiffa discusses this in The Art and Science of Negotiation (2003) and, as co-author, gives an introduction to multi-criteria analysis in Smart Choices (2003). From legal negotiations it is then not a big step to, as in this book, use MCA in other areas, such as for analyses of legal situations and decisions. As concerns the use of MCA in Alternative Dispute Resolution (ADR), reference can be made to Nagel and Mills, Multi-criteria Methods for Alternative Dispute Resolution (1990). This book shows how computer support can be applied as a tool for using MCA in negotiations and legal disputes. ${ }^{12}$ Fuzzy logic seems to receive a bit more attention in the field of evidentiary law than it does in regard to legal assessments, ${ }^{13}$ but even here legal literature is sparse. ${ }^{14}$ One explanation for the difficulty MCA and fuzzy logic have had in gaining a foothold in the field of law might be that the literature in this subject is written in a different scientific language than law professionals may be used to; a language that is furthermore

12 Another book about computer support is, for example, Alessio Ishizaka and Philippe Nemery, Multi-Criteria Decision Analysis: Methods and Software (Wiley 2013).

13 However, see TT Arvind and Lindsey Stirton, 'Explaining the reception of the Code Napoleon in Germany: a fuzzy-set qualitative comparative analysis' (2010) 1 Legal Stud. 1. Also see Odelstad, who is cited in the next section.

14 See, for example, Kevin M Clermont, Death of Paradox: The Killer Logic Beneath the Standards of Proof (2013) Cornell Law Faculty Publications, Paper $585<$ http://scholarship.law.cornell.edu/facpub/585> and also Conjunction of Evidence and Fuzzy Logic (2012) Cornell Legal Studies Research Paper 12-58 $<$ http://papers.ssrn.com/sol3/papers.cfm?abstract_id=2115200> (retrieved 21 July 2016). 
often quite formal and may seem at first glance rather unapproachable for a lawyer.

This book is about the use of multi-criteria analysis (MCA) in a legal context with regard to overall assessments and balancing of interests. ${ }^{15}$ However, MCA can also be used in other law contexts than judicial processes. For the legislator who is considering different legislative options, the decision-making process includes the creation of alternative options, the selection of criteria and the collection of materials. MCA is also excellent to use in this context, just as legal scholars and legal decision-makers in both the public and private spheres may find the model useful for structuring and analysing a problem and as decision support. Hopefully, this book can, in a way that is more accessible to legal professionals, arouse interest in the possibilities offered by MCA and fuzzy logic.

\subsection{BALANCING AND COMBINED WEIGHTING}

Suppose that a mining company wants to divert a river in order to dry up a part of the riverbed to mine iron ore. Fishermen, indigenous peoples, some residents of the surrounding community and nature conservation advocates are opposed to this for various reasons. The fishermen claim that salmon fishing will be hurt (A) and that their leisure activity will be jeopardized (B). The indigenous people claim that reindeer husbandry will be disturbed and that they will suffer increased costs (C). Local residents claim that the landscape will be destroyed (D) and that tourism will suffer (E). Nature conservation advocates warn that flora and fauna will be disrupted $(\mathrm{F})$ and will be difficult to restore $(\mathrm{G})$. The municipality asserts that mining is important for employment $(\mathrm{H})$. The mining company claims that everything will be restored to its original condition (I).

A court would have great difficulty making an overall assessment or balancing interests of $\mathrm{A}-\mathrm{I}$ in a case like this without official objectives or guidelines for how this should be done. It would, on the other hand, be possible for the stakeholders involved to, without public guidelines or overriding objectives, come to a privately negotiated solution that looks after their interests. By giving and taking, receiving financial compensation, and imposing various types of restrictions, a negotiated solution might be reached ad hoc. If a court is to make an overall assessment or a balancing of interests, it must at least have one or more

15 Concerning the use of MCA in the interpretation and application of a rule of law, see section 4.6 .2 below. 
objectives on which to base the assessment. For example, that it must safeguard the interests of the environment, human health and nature conservation. There may of course also be guidelines for the assessment. Without objectives or guidelines, the assessment will take place in a vacuum. The legal requirements for non-discrimination and foreseeability will thus not be met, which is unacceptable in the governmental exercise of power.

Professor Jan Odelstad has written a book on balancing of interests in the application of planning legislation. ${ }^{16}$ In the book, Odelstad analyses the difference between public and private interests using multi-dimensional decision theory, but he also uses another terminology than what is used later on in this book. A short summary of Odelstad's views on balancing of interests is provided below. Those interested in the more detailed and in-depth analyses he makes are referred to his book. ${ }^{17}$

According to Odelstad, a typical decision-making situation often involves a number of options and a set of aspects that may be of significance to how good the options are. He believes that evaluation with respect to aspects is an important step in the weighting of different considerations and in the combined weighting of different aspects into a total appraisal. The total appraisal, says Odelstad, can be seen as a whole consisting of parts that in turn are wholes consisting of smaller parts, and so on. A total appraisal therefore disintegrates into parts, which in turn disintegrate into smaller parts of the same type, but which in a sense are on a different level. The problem, argues Odelstad, consists in determining the 'total goodness' or appropriateness of the options (often for a specific purpose or in a specific context). One should, in other words, make a total appraisal of the options (for that particular purpose or context). The total appraisal (or the 'total goodness', as Odelstad calls it) is achieved through a combined weighting of the original aspects, which then forms a new aspect. The task is therefore to determine what the options are in regard to this new aspect. This entails attempting to determine the ranking of the options with regard to this, that is, establish which of the options is best, second best, good, less good and bad. However, this might not be sufficient. It might also be necessary to identify how much better one option is than another. Based on how the options stand in the total appraisal, the decision, Odelstad says, is often easy to make. This may, for example, mean Sweden.

16 Professor of Decision, Risk and Policy Analysis, Gävle University College,

17 Jan Odelstad, Intresseavvägning. En beslutsteoretisk studie med tillämpning på planering (Thales 2002). 
selecting the option that is best overall or establishing a priority order for the options. ${ }^{18}$

Odelstad argues that when we speak of the interests of $\mathrm{X}$, it is more of a question of the value of $\mathrm{X}$. According to Odelstad, it is therefore reasonable to say that $X$ is a private interest if $X$ is valuable or has sufficient value from an individual point of view, and that $\mathrm{X}$ is a public interest if $\mathrm{X}$ has a large enough value from a general standpoint. ${ }^{19}$ According to Odelstad, aspects can be interests, though not every aspect. Every aspect is thus not deserving of the designation of interest. This designation is only given to aspects that are of interest, that is, that have significance or value to the assessment, balancing or weighting in question. ${ }^{20}$ Options can also be called interests, according to Odelstad. ${ }^{21}$

Odelstad calls that which is weighted together in a combined weighting, factors or components, and that which these are weighted together into, he calls aggregates. He sees both factors and aggregates as aspects and therefore uses the term 'aggregation' synonymously with combined weighting. ${ }^{22}$ This term is common in MCA and is also used at times in this book. Odelstad often uses the term 'aspect'. In MCA, the terms commonly used are attribute or criterion, objectives and options without explicit reference to aspects. This terminology is also used when MCA is discussed later in this book. Aspects will thus not be specifically mentioned, but are of course important to the assessment of different options and criteria.

Odelstad furthermore divides interests into public initial interest aspects, private interest aspects, the joined interest aspect, and the total joined public interest aspect. ${ }^{23}$ Odelstad calls the public interest that is considered in planning the 'initial public interest'. The joining of this into a total appraisal Odelstad calls the 'joined public interest' or the 'joined public interest aspect'. This aspect is, according to Odelstad, in a sense the total appraisal from a public standpoint. The combined weighting of all original aspects - both initial public interests and individual interests - into a total appraisal, Odelstad calls the 'total joined public interest' or the 'total joined public interest aspect'. This aspect is also, according to Odelstad,

\footnotetext{
18 Ibid., $70 \mathrm{ff}$.

19 Ibid., 74.

20 Ibid., 75.

21 Ibid., 85 .

22 Ibid., 86. The term 'aggregation' means, in short, that the decision basis is broken down into smaller parts to be analysed and then joined into one or more whole entities. It is this joining of the analysed components in the decision basis that is called aggregation.
}

23 Ibid., 87. 
the total appraisal from a public standpoint, but in a different sense than the joined public interest is..$^{24}$ Odelstad suggests that the total joined public interest aspect be called the agglomerated public interest aspect. ${ }^{25}$

The terminology that Odelstad uses is complicated, but has advantages. However, should the joined public interest - the agglomerate - really be called public interest? Odelstad, who asks this question himself, says that the interests, whether public or private, are of interest for the 'total goodness' because they contribute to this. According to Odelstad, the 'total goodness' is not, however, an interest because this constitutes the terminus for the assessment. ${ }^{26}$ One reason that Odelstad uses this terminology anyway is that he believes that it is not uncommon for the term 'interest' to actually be used to refer to the combined weighting of both public and private interests. Another reason is that Odelstad also views options as interests. ${ }^{27}$ The terminology thus becomes symmetrical. However, the crucial question in this context, to which this book several times returns and which Odelstad touches on, though without answering, ${ }^{28}$ is whether the 'total goodness' really is a terminus for the assessment or if there is a more total 'total goodness' above this. Perhaps this question is more about control of the assessment made than about adding another level. In such a case control probably belongs to the sensitivity assessment. ${ }^{29}$

Is there, according to Odelstad, any difference between overall assessments and balancing of interests? Odelstad argues that it is often objectives that are weighted together, that the synonymy between 'balancing' and 'weighting' is only partial and that one difference between the words is that 'balancing' is preferable when there are two phenomena that will be brought together. For 'balancing', the idea of scales and weighing plays a role: a typical balancing uses a figurative scale, or more specifically a balance scale, and such a scale has two weighing pans. ${ }^{30}$ Another difference in use between 'balancing' and 'weighting' that Odelstad thinks exists is that a balancing more frequently concerns circumstances, whereas a weighting more frequently concerns aspects (viewpoints). Not that it is so, he says, that circumstances are always balanced and aspects are always weighted - in fact the opposite is sometimes done - but Odelstad thinks there is a tendency for this. ${ }^{31}$

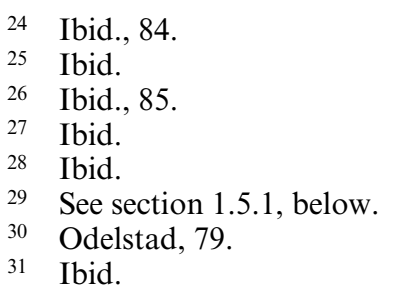


Odelstad has been given a lot of attention above, and there are two reasons for this. First, his is the only account in Sweden in which a legal balancing of interests has been investigated thoroughly based on multi-dimensional decision theory. Secondly, Odelstad's analysis of what a balancing of interests is stands out as penetrating and well executed. Admittedly, in regard to his terminology, it is rather complicated and it could furthermore be discussed whether a combined weighting of public and private interests should be called a joined public interest. If Peter, Nick and Henry have private interests that are weighted together with a public interest, and these outweigh the public interest, it may seem misleading to call this the 'total joined public interest'. If, on the other hand, this joining is done in the public interest, that is, from a common point of view, it is good if the individual interests are given priority when they weigh more. Naturally, in this case there should be a sufficiently large number of private interests.

Later in this book, examples will be given of overall assessments and balancing of interests. It will be demonstrated that in certain cases, it is not possible to draw a clear line between overall assessments and balancing of interests and that even a balancing of interests may contain an overall assessment. This is also apparent from Odelstad's investigation, even if he does not closely examine the demarcation issue. There are, however, at least sometimes, important differences in the legal conditions for performing a balancing of interests or an overall assessment, which will be discussed. The next question is if the results can differ depending on what type of assessment is made.

\subsection{EXAMPLES OF BALANCING OF INTERESTS}

In the following, a few legislative rules will first be described in which a balancing of interests must be made. ${ }^{32} \mathrm{~A}$ few legal rules that presuppose an overall assessment will then be presented. The aim is not to substantively examine in more detail what a balancing of interests or an overall assessment is in different branches of law and in different situations, but

32 Weighting norms from a legislative and legal science perspective have been discussed by, among others, Torstein Eckhoff and Nils Kristian Sundby, Rettsystemer: Systemteoretisk innføring i rettsfilosofien (2nd edn, Tano 1991). Balancing of interests from a procedural law perspective has been discussed by, among others, Hans Eklund, Inhibition (Iustus 1998) 231f and Lars Heuman, 'Avvägningsrekvisit och möjligheten för en domstol att avvisa en fastställelsetalan när käranden kan föra en fullgörelsetalan' (2006-07) JT 837. 
rather to try to determine what characterizes these. One overriding question is if there is any difference between balancing of interests and overall assessments. An important question related to this is if the same structured decision model can be used for both balancing of interests and overall assessments. It will also be examined whether, and if so how, the principle of proportionality and prerequisites such as 'extraordinary reasons' or 'special circumstances' (weights) come into a balancing of interests.

\subsubsection{Planning and Building Act (PBL)}

Balancing of interests under this law has, as mentioned above, been thoroughly analysed by Odelstad. The Preamble of the Planning and Building Act (PBL, 2010:900), 1:1, states that the provisions of the law are aimed at, with consideration to individual freedoms, promoting social progress with equal and good social conditions and a good and lasting sustainable living environment for the people of today's society and for future generations. The second chapter of the Act is entitled 'Public and private interests' and in 2:5 PBL, a balancing of interests is directly prescribed: ${ }^{33}$ 'Where issues are addressed under this Act, consideration shall be given to both public and private interests.' The Act specifies which interests should be taken into account. PBL 2:3, for example, stipulates a good living environment from a social standpoint, good management of land and water, and good economic growth. It is furthermore stipulated in the Act that certain values must be protected, including the culture-historical and environmental.

It should first be noted that when the Act states that the examination 'of issues under this Act' shall consider both public and private interests, this does not mean that every issue will be subject to a balancing of interests. An issue under the Act could, for example, be whether or not something is a 'building product' or how the term 'property developer' should be interpreted. The intent would not seem to be that such matters should be resolved by a balancing of interests, but rather that planning should be decided after a weighting.

The Act can require an assessment of a great number of factors, which must be categorized and classified according to the terms and designations used by the Act. If there were only two large weighing pans, one for public and one for private interests, there would be a very large amount of data in the pans that would have had to have first been weighted together in some way. For this reason, aggregation would likely be done on several

$33 \quad 1: 5$ in the official translation of PBL (1987:10). 
levels. The weighting that the Act stipulates is usually a terminus at the end of a line of many assessments. This is the incremental aggregations and the total appraisal that Odelstad speaks of. As for whether an overall assessment is made on a level above the balancing of interests or if the total appraisal is made within the balancing of interests, we will return to this overriding question later in the book.

\subsubsection{Environmental Reviews}

Stipulations 7:25 and 7:26 of the Environmental Code (1998:808) are provided under the heading 'Review of interests'. These stipulations are as follows, in the order they appear:

In connection with the consideration of matters relating to protected areas referred to in this chapter, private interests shall also be taken into account. Restrictions on the rights of private individuals to use land or water under safeguard clauses provided in this chapter must therefore not be more stringent than is necessary in order to achieve the purpose of the protection.

Exemptions from prohibitions or other rules issued pursuant to this chapter may only be granted in accordance with sections 7,9 to $11,18,20$ and 22 where this is consistent with the purpose of the prohibition or rule. ${ }^{34}$

From 7:25, it is clear that a proportionality assessment must be made. The provision in 7:26, which concerns exemptions, protects the public interest. In the grounds for this, it is stated in 7:26 that exemptions are granted for a private interest that outweighs the public interest; ${ }^{35}$ thus a balance-scale mindset and a balancing of interests. The application of the exemption rule is furthermore intended to be restrictive. ${ }^{36}$ Exemptions may only be granted if this is in accordance with the aim of the prohibition or regulation.

Balancing of interests in environmental processes has, among others, been addressed by Professor Per Henrik Lindblom. He maintains that the concept of balancing of interests in German doctrine is considered empty and meaningless and that it is difficult to determine quantitatively; at what point do private interests or third-party interests become so numerous that they become public interest? He also mentions something that he calls over-individual interests, which consists of a conglomerate of private

34 Official translation of The Swedish Environmental Code can be found in Ds (Departemental Serie) 2000:61.

35 Governmental Bill 1997/98:45, part II, 98.

36 Ibid. 
interests and claims that they cannot be individualized, such as people's claim to a good environment. ${ }^{37}$

It is easy to agree with Lindblom that balancing of interests as a legal concept lacks substance. As this book aims to present a structured model for decision support, however, the substantive meaning of the term balancing of interests will, as previously mentioned, not be examined in more detail. The balancing of interests will instead be examined from an analysis and decision perspective. Which factors should be placed in the weighing pans, as well as the weight of these factors, of course raises legal issues, but the weighting itself and the way in which this is done are determined by decision theory and the structured model used. However, some substantive decision aspects will be discussed in this context later in section 1.5.2.

\subsubsection{Camera Surveillance}

On 1 July 2013, a new camera surveillance law came into force, applying instead of the Personal Data Act (PUL, 1998:204) and replacing the Public Camera Surveillance Act (LAK, 1998:150). This Act combines all rules regarding camera surveillance into a single law. Under section 6 of the Public Camera Surveillance Act, permission shall be granted for camera surveillance if interests for such monitoring outweigh private interests in not being monitored. In assessing interests in camera surveillance, special consideration shall be given to whether monitoring is needed to prevent, detect or investigate crime, prevent accidents or for other comparable purposes.

For places where the public has access, permission for camera surveillance shall be granted if interests for such monitoring outweigh private interests in not being monitored. The individual's interest in not being monitored shall be particularly weighed against the area to be monitored and how the monitoring is carried out. ${ }^{38}$ Generally speaking, the larger the area to be monitored, the more sensitive the space (for example, toilets) and/or the longer the exposure time, the higher the infringement on privacy will be. ${ }^{39}$ The Swedish Data Protection Authority has

37 Lindblom, Miljöprocess, del 1 (n 10) 77-98. Also see Robert Nordh, Talerätt i miljömål: Särskilt om vattenrättsliga ansökningsmål samt talan rörande allmänna intressen (Iustus 1999) 370ff.

38 See for example Supreme Administrative Court annuals RÅ 2000, ref. 61 on the weighting itself and RA 2010 ref. 22 on the monitoring of streets and public squares.

39 Regarding factors to consider, see Kristina Blomberg, Värt att veta om personuppgiftslagen (Studentlitteratur 2012) 32. 
checklists for employers and for schools considering introducing camera surveillance.

As stated in the Swedish Data Protection Authority's information leaflet of June 2013, permission under the 'The new Camera Surveillance Act' is based on an assessment according to the principle of preponderance of evidence. ${ }^{40}$ An important feature of the principle of preponderance of evidence is, according to the Data Protection Authority, that camera surveillance is normally not to be seen as a first-choice option for achieving a particular purpose. It should therefore first be examined if less intrusive options can be considered, such as lighting or the presence of security guards.

Of particular interest from a procedural law angle is the Data Protection Authority's reference to the principle of preponderance of evidence. In procedural law doctrine, this principle is only used in issues of evidence while the Data Protection Authority seems to use this in matters of both evidence and law. See also RA 2000, ref. 61:

Under section 6 of the Public Camera Surveillance Act (LAK), permission shall be granted for camera surveillance if interests for such monitoring outweigh private interests in not being monitored (the so-called principle of preponderance of evidence). In assessing interest in public camera surveillance, special consideration shall be given to whether this is needed to prevent crime, prevent accidents or for comparable purposes. In assessing private interests in not being monitored, special consideration shall be given to how the monitoring is conducted and to the areas to be monitored. (My emphasis, my translation)

It is evident from this quote that the Supreme Administrative Court uses the principle of preponderance of evidence not only in the existence of facts, but also to weigh the legal implication of the factors that are in each figurative weighing pan. The question of what the term 'privacy' entails and if, and to what extent, the monitoring is an invasion of privacy, is unquestionably an issue of law. From a procedural angle, it is thus about a different use of the principle of preponderance of evidence than the usual. This indicates that the principle of preponderance of evidence in camera surveillance is used as a decision rule for the entire weighting operation. We will return to this use of the principle of preponderance of evidence later. ${ }^{41}$

$40<$ http://www.datainspektionen.se/press/nyheter/2013ny-kameraovervakningslag-fran-1-juli/> (retrieved 15 August 2014).

41 Section 1.5, below. 
The right to privacy is protected in article 8 of the European Convention on Human Rights (ECHR). However, ECHR permits exceptions because there are times when the individual must tolerate infringement on the person's private life if this is needed to, for example, prevent crime and if the intrusion is reasonable in relation to the interests of society. The principle of proportionality must therefore be considered in the application of the Camera Surveillance Act.

\subsubsection{Tenancy Act}

In chapter 12 of the Swedish Land Code - the 'Tenancy Act' - there are a number of provisions that refer to balancing of interests. Section 46 , section 1 , clauses $1-10$; for example, specify when a tenant's legal protection of tenancy may be withdrawn. Clause 10 - the general clause - provides for a balancing of interests. A prerequisite for this is that there must be substantive grounds for moving out. On weighting, the Tenancy Act Committee states:

Of importance should also be how the weight of the substantive grounds relates to the weight of the tenant's interest in retaining the flat. A substantive ground should, for instance, not entail the sacrifice of an urgent interest in maintaining the residence. The substantive grounds must have such weight that it appears reasonable or fair that the tenant must move. It is quite natural that a balancing of interests of this type, which is required here, must in situations with troubling housing shortages normally tip the scales in favour of the tenant. In such market conditions, the matter at hand is, for the tenant, of such vital interest as having a roof over one's head. Even if the tenant also, in a reasonably balanced market, has a major interest in retaining the leased rental unit, this interest is, however, not one of such magnitude that it should, to the same extent as in a noticeable housing shortage, tip the scales in favour of the tenant. This assessment is consistent with the statement at the inception of the Tenancy Act, that the Act's extension rules in housing shortages should to a certain extent protect the tenant even against terminations for reasons that would otherwise be considered fully legitimate. What this matter, in market conditions without housing shortages, chiefly entails for the tenant is the idealistic interest in keeping one's home intact and continuing to live in the place where one has grown into the environment and become comfortable in it. For a family with children, the interest in remaining undisturbed in the home of course carries particular weight. This idealistic interest, which is thus linked to the preservation of the home in the leased residence, is, however, not the only factor, which more generally can be considered to speak in favour of allowing the tenancy to continue. Consideration must also be given to the fact that a move generally involves expenses for the tenant, which are often considerable in comparison to the tenant's economical resources, in any case if expenses for alterations and acquisitions of furniture, fixtures and similar are also to be taken into account. Even other factors, such as the distance between home and work, could at times 
play a role when it comes to assessing the tenant's interest in maintaining the rental unit. ${ }^{42}$ (My translation)

The Committee's statement is a good and clear example of balance scale thinking (see reference to 'weighing pans'). In other words, there must be substantive grounds. The weight of these substantive grounds must then be weighed against the tenant's interests. If these substantive grounds have a low weight, the interest in maintaining the residence must not be sacrificed. The Committee further differentiates between a situation in which there is a housing shortage and a situation in which there is not a housing shortage. In the latter, the tenant's idealistic interest in remaining in the residence and the costs of a move are mentioned.

In NJA 2011 p. 27, concerning the application of 12:57, paragraph 1, clauses $2-4$, it is stated that the landlord in cases of demolition and renovation does not need to give reasons for demolition or renovation, and that this therefore represents a type of legal balancing of interests. This expression thus means that the balancing of interests is set out on beforehand in the law. ${ }^{43}$ Later on in this book this will be referred to as legal balancing of interests, in contrast to, as in the Committee's example above, law-based balancing of interests.

\subsubsection{Optional Rules - Procedural Weighting}

That the court, in accordance with an optional provision in RB, 'may' do something usually means that there is a balancing of interests. An example of a 'classic' procedural weighting rule is the provision for declaratory claim in $13.2 \mathrm{RB} .{ }^{44}$ The declaratory claim may be admissible for examination if it is deemed appropriate. The plaintiff's interest in having an uncertain legal situation determined must be weighed against the defendant's interest in not suffering 'prejudice' by the uncertainty being removed. Even in the production of a document pursuant to $38: 2 \mathrm{RB}$ a balancing of interests must, in some cases, be conducted. To begin with, the prerequisites in the provision on identification, relevance and evidential significance of the required document must be met. If the opposing party alleges that

42 SOU 1961:47, 90, also see SOU 1966:14, 209, Government Bill (1968:91) and Leif Holmqvist and Rune Thomsson, Hyreslagen. En kommentar (10th edn, Norstedts Juridik 2010) 507ff. Also see Bertil Bengtsson, Richard Hager and Anders Victorin, Hyra och annan nyttjaderätt till fast egendom (8th edn, Norstedts Juridik 2013) 60ff.

43 Bertil Bengtsson and others, ibid., 110.

44 Heuman (n 32). 
the documents contain trade secrets, 'extraordinary cause' is furthermore required for disclosure of the documents. The evidentiary value of the documents must then be weighted against the risk of injury. ${ }^{45}$ Because the effort involved in disclosing documents can be burdensome, involving, for example, months of work to find data files, the effort must also be proportional to the claimant's interest in obtaining the documents.

A balancing of interests must also in certain cases be done in the use of preliminary seizure in accordance with 15:1-3 RB. The provision in 15:3 RB may thus require a balancing of interests. ${ }^{46}$ In RH 2001:10, the Court of Appeals rejected, after a proportionality assessment, a motion for sequestration, even though the prerequisites specified in 15:1 RB were met. The Court of Appeals, however, found it possible to conduct a balancing of interests even in the decision on sequestration, referring to NJA 1993, p. 182, which provides that this is possible.

Balancing of interests can be triadic. In the application of the abovementioned 13:2 RB, two private interests - the plaintiff's and the defendant's - can be weighed against each other, but public interests for expedient proceedings must also be taken into account. It is perhaps for this reason that the Supreme Court used the word 'appropriate' in this context. ${ }^{47}$ In such a case it is not a balancing of interests such as is done when decisions are made on camera surveillance, where public interests are weighed against private interests. On the other hand, public and private interests are included in virtually all types of interests. In a document production dispute amenable to out-of-court settlement, the individual claimant's interests in obtaining the document are placed against the individual possessor's interests. Could there be a public interest in producing the documents that should also be considered so that the weighting becomes triadic? It could be argued that there is a public interest in effective and expedient litigation or arbitration, but this interest is so general that it then applies to the application of all rules in RB or in the Arbitration Act. In principle, it should therefore not have influence on the balancing of two private interests in a dispute amenable to out-of-court settlement.

Trade secrets are protected by law because there is a public interest in protecting them. ${ }^{48}$ For this reason, 'extraordinary cause' is required for

45 See for example NJA 2012 p. 289, concerning the court's examination of an application for a subpoena for the production of a document in arbitration.

46 Eklund, Inhibition 235 (n 32) and Peter Westberg, Det provisoriska rättsskyddet i tvistemål. En funktionsstudie över kvarstad och andra civilprocessuella säkerhetsåtgärder, Bok 1 (Jurisförlaget Lund 2004) 18.

47 NJA 2005 p. 517 , NJA 2007 p. 108.

48 Act on the Protection of Trade Secrets (1990:409). 
the production of documents which the adversary claims contain trade secrets. However, this might well be the case even with regard to the party petitioning for disclosure; it depends on what law is invoked. ${ }^{49}$ Anyway, as soon as an overall suitability assessment comes into the picture for a balancing of interests, the question clearly arises as to whether another level is added to the assessment: an overall assessment on top of a balancing of interests..$^{50}$

\subsection{OVERALL ASSESSMENTS}

Overall assessments typically include a variety of circumstances and considerations. While it is claimed that balancing of interests would seem to require support in law or preparatory work ${ }^{51}$ - which seems doubtful the same does not apply to overall assessments. The reason for this is that it is inherent in its very nature that an overall assessment must be made when there are several factors to be weighted together. The word 'overall assessment' is not always used in court practice as a designation for this combined weighting. Other common expressions are in a collective assessment', 'all in all, we find. ..' and similar formulations. However, if it is expressed in the preparatory work that an overall assessment must be made, these tend to be referred to in the reasons for the judgement.

That an overall assessment will be made does not necessarily mean that this is difficult or that it includes a large number of factors. It may be that there is a circumstance that is prominent and significant, a single circumstance that knocks out all the others or at least achieves dominance. ${ }^{52} \mathrm{In}$ such cases, the overall assessment is easy. There are also overall assessments in which the same type of event has occurred several times and must be assessed once again along with the previous, for example if an employee is dismissed because of repeated inappropriate behaviour. When similar things have happened previously the overall assessment aims at putting the events together to determine if they are sufficient for a dismissal. For the use of MCA, however, it does not matter if it is the same event or several different types of events that need to be assessed, because

49 For example, the party petitioning for disclosure claims that the defendant has infringed on his or her right to a patent.

50 Cf Odelstad (n 18) and the 'total goodness'.

51 Kent Källström, 'Arrendators ersättningsrätt vid uppsägning av anläggningsarrende. Om ändamålstolkning av avvägningsnormer' (1988) SvJT 622. However, as will be discussed later, there are different types of balancing of interests.

52 See section 4.4.6, below. 
an overall assessment in both cases means that a choice has to be made between dismissal and non-dismissal according to a number of criteria.

\subsubsection{Best Interests of the Child}

A typical example of when an overall assessment must be made can be found in the provision of 6:2a FB on 'the best interests of the child', even if this is not actually stated in the wording of the law. According to Utredningen om barnets rätt (Investigation on Children's Rights), which was started in 1977 and completed with the report SOU 1979:63, children need:

- care and protection;

- people who they can receive love from and give love to;

- a stable and lasting relationship with their parents;

- to develop in an environment that meets their needs for stimulation;

- parents' help setting boundaries for their actions;

- to feel that they are needed and that they can take responsibility;

- to be able to influence their situation;

- to gradually free themselves from their dependence on their parents;

- togetherness with both parents even if they are in conflict with each other. ${ }^{53}$

These criteria, which are based on what a child typically needs, still largely apply today. ${ }^{54}$ In addition to the above needs, the official report states that in the assessment of 'the best interests of the child', 'particular importance should be attached to' the risk that the child or another person in the family is being abused or that the child is unlawfully taken away or kept or otherwise mistreated, and of the child's need for close and good contact with both parents. It has been argued that these factors constitute presumptions. ${ }^{55}$ In a structured overall assessment, it is more likely a question of factors that are given greater weight than others. The child's need for participation has further been emphasized through a reminder in the provision that the child's wishes must be considered, taking into account the child's age and level of maturity, when decisions are made on custody, residence and visitation (6:2a, paragraph $3 \mathrm{FB})$.

\footnotetext{
53 SOU 1979:63, 56.

54 Anna Singer, Barnets bästa. Om barns rättsliga ställning i familj och samhälle (6th edn, Norstedts Juridik 2012) 27.

55 Göran Ewerlöf, Tor Sverne and Anna Singer, Barnets bästa: om föräldrars och samhällets ansvar (5th edn, Norstedts Juridik 2004) 79.
} 


\subsubsection{Contracts Act, Section 36}

Another typical example of a provision that requires an overall assessment is section 36 of the Swedish Contracts Act (AvtL) and the assessment of whether a condition in an agreement is 'unreasonable'. This general clause, which is mandatory, has been called the Contracts Act's perhaps most important provision. ${ }^{56}$ It can be applied in virtually any property law agreement. According to the legal doctrine, unreasonable is a relational concept. ${ }^{57}$ In the preparatory work, no method is given for how the provision should be used and there is, according to von Post, no definitive ruling from the Supreme Court or the appellate courts where a term has been found unreasonable in itself. ${ }^{58}$

The formulation of the general clause makes it possible to consider all factors that may be significant to the contractual relationship. Even if the provision is aimed at the terms of a contract, it is an overall assessment that is conclusive. ${ }^{59}$ Regarding the content of the agreement, the starting point for the assessment should, according to the preparatory work, be what without the term would be normal. Furthermore, an assessment is needed of how large the deviation from the normal must be for the term to be considered unreasonable. ${ }^{60}$ Concrete factors that according to the preparatory work can be significant include, for example, that the ruling is put in a superior party's hands or disproportion between the benefits the agreement gives the parties (particularly if the agreement is not commercial). ${ }^{61}$ Furthermore, the relationship between breach of contract and the consequences of this can be significant, as can attempts to circumvent existing law. ${ }^{62}$ As regards circumstances at contract inception, sections 28-31 and 33 of AvtL can, depending on the circumstances, be applied instead. In such circumstances, either the provisions mentioned or section 36 of AvtL can be used. This last rule can, however, also be applied to certain circumstances that do not fall under sections 28-31 or 33 of AvtL, such as the withholding of important information or poor language

\footnotetext{
56 Kurt Grönfors and Rolf Dotevall, Avtalslagen. En kommentar (4th edn, Norstedts gula bibliotek 2010) 237.

57 Jan Ramberg and Christina Hultmark, Allmän avtalsrätt (Norstedts 2000)

192, Grönfors and Dotevall, ibid., 246.

58 Claes-Robert von Post, Studier kring 36 § avtalslagen med inriktning på rent kommersiella förhållanden (Jure AB 1999) 97.

59 Government Bill 1975/76:81, 106.

60 Ibid., 166 and Ramberg and Hultmark (n 57) 192.

61 SOU 1974:83, 132.

62 Government Bill 1975/76:83, 120.
} 
skills. ${ }^{63}$ Other circumstances that can be considered are whether a party has abused their negotiating position through surprise tactics or has behaved aggressively. Consideration can also be given to incorrect or misleading information provided by a stronger party, even if this was done in good faith, or if the party provided information on a future action that did not occur due to unforeseen circumstances. A lack of knowledge with respect to the weaker party can also be taken into account. According to this argument, circumstances of this type should be able to be considered even in commercial relationships, but they are given particular importance in consumer relationships. ${ }^{64}$ Particularly in long-term contractual relationships, subsequent events ${ }^{65}$ can lead to modification and in exceptional cases nullity, unless these changes could not be foreseen or the parties have built some mechanism into the agreement that compensates for this. ${ }^{66}$

Other circumstances refer to factors that can be significant in the assessment of reasonableness. This could be good business practice in the industry or the parties' earlier practices. ${ }^{67}$ If it concerns a situation in which the parties have previously signed several agreements, terms from previous agreements can affect the assessment of a subsequent agreement. ${ }^{68}$ Consideration of third parties should not affect the assessment. ${ }^{69}$ If a distinction is made between the parties on the basis of gender, age, ethnicity or nationality, this is a matter of discrimination. This should, according to the preparatory work, be invokable as grounds for modification. Financial differences are not deemed to be discriminatory. ${ }^{70}$

The possibility of taking into account inferior status enables a generous application in relation to the weaker party; a consumer-friendly interpretation, according to Hultmark and Ramberg. ${ }^{71}$ In a dispute between business owners, one of them may hold an inferior position in relation to the other, which in this case can be taken into account. ${ }^{72}$ With the support of the provision, the term can be modified, the agreement modified in another respect, or the agreement nullified. It should also be possible to set aside a term and modify the entire agreement if there are

\footnotetext{
63 Axel Adlercreutz and Lars Gorton, Avtalsrätt (Norstedts Juridik 2011) 300.

64 SOU 1974:83, p. 132ff. See von Post (n 58) 159.

65 Adlercreutz and Gorton (n 63) 300.

66 Ramberg and Hultmark (n 57) 90. In consumer relationships, there is greater potential for modification on this ground, Government Bill 1975/76:81, 127.

67 Adlercreutz and Gorton (n 63) 300.

68 SOU 1974:83, 158.

69 Ibid., 160.

70 Ibid., 147f.

71 Ramberg and Hultmark (n 57) 91.

72 Government Bill 1975/76:81, 117, 137.
} 
several unreasonable terms. The court has full freedom to choose the most suitable solution, provided that this is possible with regard to the party's claims and allegations. ${ }^{73}$ Modification can be better than nullification if the parties wish to maintain a good business relationship. ${ }^{74}$

When a term is modified, its content is changed. This may concern terms on deadlines, penalty reduction or damage compensation amounts. This may particularly be the case in unforeseen circumstances. ${ }^{75}$ The aim of the adjustment is to make the term acceptable. It does not need to mean that the contractual relationship between the parties has to be equal. ${ }^{76}$ Setting aside the term means that the agreement is applied as though the term were not there. If this is impossible or inappropriate, other terms in the agreement can be modified so as to remove or mitigate the unreasonableness of the term. If it is not possible to divide the agreement up in this way, it can instead be declared completely null and void.

It is not intended that any of these solutions should prevail as a standard solution, but the courts should first seek to modify a contract term so that an inappropriate dispositive rule does not come to regulate the contractual relationship between the parties instead. ${ }^{77}$ In practice, however, it is most common to completely set aside a term. ${ }^{78}$ von Post says that there is no cut-and-dried case in which an agreement has been modified in parts other than the term in question and that there is no case in which an agreement has been declared null and void. ${ }^{79}$

\subsubsection{Other Overall Assessments}

Overall assessments are often made in sentencing. Sentencing will be analysed in Chapter 4 using multi-criteria analysis. Regarding procedural stipulations, the choice between attendance in person and participation through video conferencing also requires an overall assessment. A structural analysis of this type of situation is provided in Chapter 4. Another classic example of an overall assessment can be found in the provision on the free evaluation of evidence; after an assessment of everything that has occurred in the case during the main hearing, the courts will determine what has been proven. There are also situations where there seems to be

\footnotetext{
SOU 1974:83, p. 121.

Ibid., 133.

Ibid., 120.

Ramberg and Hultmark (n 57) 91.

Government Bill 1975/76:81, 110.

von Post (n 58) 256.

79 Ibid., 258.
} 
both a balancing of interests and an overall assessment, for example under the Personal Data Act. ${ }^{80}$ This will be discussed in more detail later in the book, where it will also become clear that the terms balancing of interests and overall assessment are not used consistently. Overall assessments are made, when necessary, in many other cases than those mentioned here. See, for example, NJA 2013 p. 689 and the application of 5:2 of the Swedish Bankruptcy Act (1987:672), which provides that the payment of clearly unreasonable salary claims can be refused and where in the preparatory work, Government Bill 1986/87:90 p.228, it is stated that the question is to be answered after an overall assessment. In NJA 2008 p. 457, which concerned the question of whether a so-called mixed gift would constitute the recipient's private property, the Supreme Court cited 'in an overall assessment. .. On the whole, overall assessments appear often and in diverse branches of law. It would be virtually impossible to give a full account of when these occur.

\subsection{WHAT ARE THE DIFFERENCES BETWEEN BALANCING OF INTERESTS AND OVERALL ASSESSMENTS?}

The example above demonstrates that there are some differences between balancing of interests and overall assessments. The starting point for the first of these is often - but not always - that there is a legally protected interest, for example, shoreline protection, tenure, or right to privacy. I call these law-based balancing of interests. They should be differentiated from legal balancing of interests, which are characterized by the fact that balancing of interests is already laid down on beforehand in the law. ${ }^{81}$ If a legally protected interest were absolute and inviolable, a balancing of interests would not be possible. A balancing of interests thus presupposes that the protected interest may give way if there is a strong enough counter-interest. The weaker the protected interest is, the easier it will be to counterbalance it.

Other characteristics of balancing of interests are that the real and practical measure through which the protected interest is set aside usually lies in the future and that the court or decision-maker at the time of the decision must take a position on whether the protected interest should be preserved intact or if the action which is being sought or otherwise

80 See section 1.3.3, above.

81 See section 1.3.4, above. 
actualized should be permitted and allowed to encroach on the protected interest. The action that the balancing of interests concerns thus requires an approval, in the examples above by the municipality (initially), rent tribunal or Data Protection Authority. Sometimes the examination of the matter coincides with the action itself. For example, the question of whether a declaratory claim will be entertained and a declaratory judgement rendered are examined in the same lawsuit. It is common, however, that there is an interval of time between the approval of action and the execution of it. If, for example, a petition for disclosure under 38:2 $\mathrm{RB}$ is approved, the claimant normally will not receive the documents immediately; it may take a while.

If the balancing of interests is supported by an optional rule in RB, it can be said to be law-based, because the law prescribes, or in any case implies, that a weighting is to be done between the different interests. The optional procedural rules, however, do not concern legally protected interests. The balancing of interests is due only to the fact that there are two parties standing against each other with different interests in the case. However, they are - with respect to procedure - equally protected by the law. It is furthermore typical of balancing of interests that, regardless of whether it is legal or law-based and affects a legally protected interest or otherwise, there should be a basis for this; certain necessary conditions must be met. Returning once again to the example above with law-based balancing of interests, there must be a shoreline protection, tenure and a right to privacy. If this were to be contentious, the examination of the prerequisites would be a preliminary issue in the case. As far as the application of 13:2 RB is concerned, there should be a legal relationship and this should be uncertain. It would seem, however, that the prejudicial prerequisite should be included in the balancing of interests. Regarding the obligation to produce a document pursuant to $38: 2 \mathrm{RB}$, it is unclear to what extent the necessary conditions of identification, evidential significance and relevance must be met. ${ }^{82}$ If they are met, there seems to be no need for a balancing of interests because the petition for disclosure should be approved. In NJA 1998 p. 829, however, a weighting was done between relevance and the counterparty's interest in not having to disclose the requested documents. Thus, a proportionality assessment may also need to be done. This can be made independently or be included in the balancing of interests.

82 It should be noted that 38:2 RB does not explicitly state that a balancing of interests should be done, but has support in precedents, see for example NJA 1977 p. 254. 
The example demonstrates briefly that law-based balancing of interests are typically aimed at a future action which is characterized in that it may cause harm or inconvenience, that there is a conflicting interest that the measure should not be taken, and that certain prerequisites must be met for the action to be permitted. The point of doing a balancing of interests is removed when permission for the action has been finally granted, because the protected interest has then been set aside and cannot be appealed.

The balancing of interests is often typified, that is, it is singled out in the determination which factors should generally be accorded weight and these are described in a general way; see above on camera surveillance and that some actions normally threaten privacy for the majority. ${ }^{83}$ No assessment is usually made on the individual level because camera surveillance affects everyone who comes in proximity of the camera. An individual assessment can, however, be considered in the balancing of interests that is done under the Tenancy Act. One factor mentioned in the statement above is that a move is costly. If the tenant is wealthy, however, this does not play the same role as it does if the tenant is poor. The tenant's financial status is presumably not significant, but it should be significant what economic potential tenants have collectively to withstand the costs of a move. If it is just a single tenant, it is of course only their financial situation that becomes relevant.

There are examples of balancing of interests being done also when a mix of past, present and future events must be considered. In NJA 2012 p. 715, the question arose on the termination of trusteeship under 11:7 FB and the right of trustees to resign. The following is stated in paragraphs 14-16 in the Supreme Court's decision:

This means that a trustee, even if the need for trusteeship remains and even if no replacement has been appointed, is entitled to resign his post if he has reasonable cause to do so. In the assessment of what is reasonable cause, a weighting may be done between the trustee's motives for terminating the assignment and the need for a trustee to be continuously available. In some cases, the circumstances can be such that the trustee shall be deemed to be entitled to immediately resign his post, for example when an illness gives cause to presume he has a limited time to live. It may also be that there is a final deadline after which the trustee shall not need to remain, such as when he assumes a post that prevents continuing the assignment. The actions of a person who is put under a trusteeship may in some cases also be so severe that an immediate right to vacate the post should exist. In general, however, the trustee must accept certain and perhaps not entirely insignificant inconvenience, as the need for trusteeship must be met

83 Section 1.3.3, above. For a discussion of what can be deemed an encroachment on privacy, see Blomberg (n 39) 31. 
while awaiting the appointment of a new trustee. Among the factors to consider in the assessment of what can be reasonably demanded of the trustee is how difficult it is for the chief guardian to find a replacement. Of significance in the balancing of interests is also the time it takes for the chief guardian to find a replacement. The longer it takes to appoint a new trustee, the lower the requirements should be for the grounds that shall be deemed sufficient for the trustee to be entitled to resign. (My emphasis, my translation)

This case concerns a decision on trusteeship and the question was whether or not it could cease. The balancing of interests comes into the legal case in retrospect. The need for trusteeship is weighed against the trustee's right to resign. From the beginning, before the trustee was appointed, there was a need and a law-based interest in a trustee so that a trustee could be appointed. A balancing of interests must then be done afterwards to terminate the trusteeship. The termination of trusteeship thus becomes a mirror image of the appointment of a trustee.

As discussed, overall assessments do not require any support in law or other legal sources, as these must be done when there are several factors to take a position on. Overall assessments most often come into play in cases where the necessary conditions of the law are open, particularly when they refer to a standard referencing socio-ethical benchmarks ('unreasonable', 'unjust') or where there is otherwise a concept with a broad and undetermined content, such as 'the best interests of the child'. However, overall assessments can also occur in situations where the applicable prerequisite at first glance seems to be descriptive but at a closer look refers to a complicated legal concept. For example, what are the necessary or sufficient legal conditions for being an 'employee'? In addition, it may concern the choice between different options (legal consequences), which could be difficult to decide on. The question of consequence in a certain case could, for example, be imprisonment or suspended sentence. ${ }^{84}$ On the whole, overall assessments in criminal cases are rather often made in the determination of sanctions as well as in the determination of the offence.

In contrast to the balancing of interests, which are targeted on future events, overall assessments seem to usually launch from a past event that must be evaluated with respect to a legal consequence. This situation is by and large the most common situation in the application of the law, because the administration of justice or judicial examination is generally retrospective and not prospective. To connect to the legal cases and the example above: Was an agreement entered? Is the agreement 'unreasonable'? Was the paid salary 'unreasonable'? Was it a gift? Was the gift a mixed gift?

84 See the example in section 4.5 , below. 
Something has thus occurred that needs to be classified in retrospect. In other cases, a past occurrence is a prerequisite for something that will occur: the accused has embezzled funds and admitted the crime. Should the sanction be imprisonment or a suspended sentence? This is a matter then of legal remedy. Thus, overall assessments can with respect to the foregoing, be explained with the traditional legal fact-legal consequence model. The agreement is a legal fact and can of course not be revoked only after a balancing of interests (pacta sunt servanda). A legal counterfact is required in order to revoke it. ${ }^{85}$ Or there is, as in 5:2 KL, a wage claim legal fact - which is not fully sustained because it is 'unreasonable'. The question of how something can be legally qualified can also, as in NJA 2008 , p. 457, be determined after an overall assessment, in which the nature of the legal fact is decided.

The attentive reader has already noted that 'the best interests of the child' does not fit into this explanatory model. In this case, it concerns a legal fact that projects into the future. Should not then the question of 'the best interests of the child' be determined after a balancing of interests instead of an overall assessment? ${ }^{96}$ The answer is no. 'The best interests of the child' can of course be said to be a protected interest, but it is of a different nature than the protected interests provided in the examples above: shoreline protection, tenure and right to privacy. These interests have been protected by law, but in another way than as 'the best interests of the child'. If both parents want sole custody and shared custody is not an option, the law does not favour either parent at the start, but rather it is an open question of who should get custody. In contrast, shoreline protection, for example, is already present from the start. The custody issue is furthermore not about the parents' interests, but instead about what is best for the child, although it could be debated whether in this case the issue should be regarded to concern a law-based balancing of interests - in this case between the child and the parents. Such a model, however, would risk being conflict-driven, although on the other hand put the child's interests in focus in a clearer way than an overall assessment. This issue, which will not be investigated here, may perhaps merit a closer examination.

NJA 2008 p. 55, which concerns permission for water activities, states that:

85 A legal counter-fact, if proven, means that another alleged legal fact does not have the legal consequence it otherwise would have had.

${ }_{86}$ As noted above, an overall assessment shall be made in accordance with the preparatory work. 
Under chapter 11, section 6 of the Environmental Code, water activities may be conducted only if their benefits from a public and private perspective outweigh the costs, damage and inconvenience of these. The review shall consist of an overall assessment of the water activities and the primary objective shall be to prevent water activities that are not justified in terms of public finances. As the Swedish Land and Environment Court of Appeal has found, the benefits from a public and private standpoint outweigh the costs, damage and inconvenience, and therefore, the decision of Swedish Land and Environment Court of Appeal to permit water activities shall be established. (My emphasis, my translation)

This case deals with permission to conduct water activities. A weighting was done in which the benefits were weighed against the costs, damage and inconvenience, that is, the drawbacks. In the grounds for the judgement, the expression 'outweigh the costs' is used, which indicates a weighting. The purpose of the weighting is to prevent water activities that are harmful from a perspective of public finances. The interest meriting protection is thus public finances. Why is it then said in this case that the review should be an overall assessment? The case can be compared with NJA 2013 , p. 441, in which the claimant was demanding a utility easement for a 30-metre wide corridor. Under section 6 of the Swedish Utility Easements Act (1973:1144), utility easements may not be granted if the objective should more suitably be met in another way, or if public or private inconvenience of granting such outweighs the benefits that can be gained. The Supreme Court stated the following:

As regards the balancing of interests under section 6, the preparatory work does not provide any strict direction for the application of the law (see Government Bill 1973:157 p.100 f. and 131 f.). Nor is there any guiding case law. It is, however, clear from the preparatory work that the provision has been designed on patterns from the corresponding rule in chapter 2, section 12, first paragraph of the Expropriation Act (1972:719). It can be concluded from this that the weighting shall take into account all relevant interests and that consideration shall be given not only to financial but also idealistic value (see Government Bill 1972:109 p. 219). (My emphasis, my translation)

The assessments in these cases are similar, but in the one an overall assessment was made and in the other a balancing of interests. In essence, the same sort of assessments have certainly been done, but there is reason to discuss two aspects of them. The first case (NJA 2008 p. 55) concerns protected interest, this means, simplified, that the assessment does not start in a substantively neutral position, The same is true with respect to the second (NJA 2013 p. 441). Compare: 'water activities may only be conducted if' and utility easement may 'not be granted if the objective should more suitably be met in another way'. Anyone petitioning for water 
activities under 11:6 MB or for a utility easement thus has an uphill battle as the opposing interests are protected by law. This would also manifest itself if the facts were uncertain; the burden of proof would then probably fall on the party petitioning to conduct water activities or be granted a utility easement.

NJA 2008 p. 55 speaks of benefits from public and private perspectives and assesses whether these outweigh the costs, damage and inconvenience of the water activities. Five factors are thus named. Using the weighing pan analogy, these five factors would need to be combined into two categories, which is fully possible if benefits from public and private perspectives are put in one pan and the costs, damage and inconvenience in the other. In this case, however, the factors must first be weighed together, which presupposes an overall assessment, which is then done before the balancing of interests. Alternatively, several weightings are done, which end in an overall assessment. In the second legal case, NJA 2013 , p. 441, it seems that the assessment was preceded by overall assessments and concluded with a combined balancing of interests. These two legal cases demonstrate what was discussed previously, that aggregations are done on several levels in the balancing of interests and overall assessments. If, in a legal case, it is stated in the reasons for the judgement that weighting has been done, but at the same time in the closing remarks it is stated that an overall assessment was made, this is not a contradiction but instead depends on the number of levels in the assessment and how the aggregations were done. However, when it is stipulated in law or is apparent by law that a balancing of interests must be done, it is inappropriate to write in the reasons for the judgement that an overall assessment has been made, even if the weighting actually ended with the weightings being combined after an overall assessment, because this can lead to misunderstandings.

When the court decides on whether video conferencing will be used in a hearing, an overall assessment must, under the Government Bill, be conducted of all relevant circumstances. ${ }^{87}$ The importance of the person appearing in the courtroom must be weighed against the circumstances suggesting that he or she should appear in another way. ${ }^{88}$ When, on the other hand, it concerns the taking of evidence outside the main hearing and questioning by telephone - where basically the same type of assessment must be made - it is stated in the Government Bill that a balancing of interests must be made between the examination and the importance of

87 Government Bill 2004/05:131, 95.

88 Ibid., $92 \mathrm{ff}$. 
the case on one side, and on the other, the costs for the appearance of the witness in the hearing and the inconvenience of appearing at court. ${ }^{89}$ Also see NJA 1998 p. 862, where the Supreme Court stated:

Under the provision of chapter 46, section 7, paragraph 2 of RB, examination in the main hearing of a criminal trial may be conducted by telephone only if one of two conditions exist [...] Under the second alternative, examination may be conducted by telephone if the taking of testimony under the usual rules would result in costs or inconvenience that are not reasonably proportionate to the importance of hearing the testimony in such a way. Under that alternative, a balancing of interests shall be done, leaving some room for questioning by telephone, even if such a questioning does not seem fully equivalent with examination directly before the court. For questioning by telephone to be acceptable, however, the objective of taking evidence orally must be substantially met even by telephone (referred Government Bill, ibid). Of importance with respect to the balancing of interests is, among other things, the nature of the case and the weight of the evidence in the assessment of the case. (My emphasis, my translation. The Government Bill referred to is Bill 1986/87:89 p.220, the relevant provision is now 5:10 RB).

Today, the same conditions for using telephone conferencing apply as for video conferencing, albeit that the conditions in each case can be applied somewhat differently. This means that the courts in their position on questioning by telephone must make an overall assessment. Thus, what was previously deemed to be a balancing of interests has now become an overall assessment. However, the different designations of overall assessment and balancing of interests made by the lawmaker do not seem to have any difference in substance. They are in these contexts exchangeable.

\subsubsection{Final Overall Assessment or Balancing of Interests?}

As already discussed, an aggregation process means that both balancing of interests and overall assessments can exist in the same decision-making process. This will be illustrated in more detail in this section. Section 11 of the Personal Data Act (PUL) contains a provision under which personal data may not be processed for purposes directly related to marketing, unless the registered person has declared in writing that he or she is opposed to such processing. As in several other cases under PUL concerning protected interests, a balancing of interests must be done. What is interesting is that the Data Protection Authority in the publication

\footnotetext{
89 Ibid., 95.
} 
'Intresseavvägning enligt personuppgiftslagen' ("Balancing of interests under the Personal Data Act" (2009) writes the following: ${ }^{90}$

In the overall assessment made in the balancing of interests, consideration should be given to the following: ${ }^{91}$

The purpose (aim) of the processing.

Who the marketing is directed at (for example, private individuals or businesses, or if the target group needs special support, such as in the case of children).

The scale of the marketing.

What type of personal data will be processed (for example, information that under the Personal Data Act is deemed sensitive or innocuous information such as address details).

If the processing entails detailed knowledge about the registered person.

How the information is processed.

If the information requires special protection.

If there is a right to oppose processing under section 11 of PUL (for example, through the Swedish service to block unwanted telephone sales, the NIX registry).

The security and sorting procedures in place for the collected data.

If there are special provisions in laws or regulations that must be considered, such as confidentiality stipulations.

If company agreements in the area are complied with (for example, Swedma's rules for the use of personal data in direct marketing).

The information provided to the registered person.

(My emphasis, my translation)

Before continuing this discussion, it should also be noted that the Swedish Labour Court in judgement 2010 no. 87 (breach of collective agreement) states that:

In a judicial review under section $10 \mathrm{f}$ of the Personal Data act, a balancing of interests shall be done after an overall assessment has been made of all circumstances in that particular case. (My emphasis, my translation).

The legal case indicates the order in which the Swedish Labour Court has performed the reviews: an overall assessment is first made, and then a balancing of interests. When the Data Protection Authority says that an overall assessment shall be made in the balancing of interests, it would seem to mean the same thing. These decisions indicate that what is primary and decisive is the balancing of interests, regardless of whether it is done before or after an overall assessment or if the overall assessment

$90<$ http://www.datainspektionen.se/documents/faktabroschyr-intresseavvag ning.pdf $>$ (retrieved 5 October 2014).

91 The same is stated in the Data Act Committee's report, see RA 2001, ref. 68. 
is done along with the balancing of interests. This is essentially because it is about law-based protected interests and that the balancing of interests therefore also has significance as a decision rule, which will be discussed further below.

The 13 conditions listed on the Data Protection Authority website contain various types of factors. Naturally, all 13 will not occur in one particular case, but a number of them are always included in the assessment. Each point on the list may involve several concrete circumstances and these may overlap each other so that one single factor occurs on more than one point on the list. An aggregation is done on several levels, meaning that some factors are sorted and packaged into groups into which they are deemed under some principle to belong, thereby obtaining a number of overall-assessed 'packages' for and against what is placed in each weighing pan. After the overall assessments have then been made, the balancing of interests comes in because such is stipulated in the law. The balancing of interests becomes the final station and thus functions as a decision rule. Of course, it is not certain that the decision-maker needs to go the entire distance. Some preliminary assessments can provide the answer at an earlier stage in simple cases.

The idea that an overall assessment should be done alongside balancing of interests or within it may signify that overall-assessed circumstances in the weighing pans that are balanced according to interests then, finally, become subject to an overall assessment. In such a case, this total appraisal is made on a level above the balancing of interests. However, even if this is true, the law-based balancing of interests must function as a decision rule; the overall assessment then represents a reconciliation of what has already been assessed and a final control of the balancing of interests and possibly a final fine-tuning of it. ${ }^{92}$

As discussed above, the difference between an overall assessment and a balancing of interests emerges in the decision-making situation, in any case if it is a law-based balancing of interests. Suppose that it had been stipulated in section 6 of the Camera Surveillance Act that the issue should be decided after an overall assessment and not through a balancing of interests. Would this make a difference in the way the issue was assessed or in the results of the assessment? And would it, to take another example, similarly make a difference in the assessment under the Environmental Code if an overall assessment had been stipulated instead of a balancing of interests? If the answer is that it makes no difference, it becomes a matter of indifference how the lawmaker expresses itself. If the answer is instead

92 Cf the sensitivity analysis described in section 2.3 .8 , below. 
yes, it does or may have significance for the results, there is an important difference.

According to Odelstad, a weighting often concerns factors, while a combined weighting more often concerns aspects. But, as mentioned above, he also believes that objectives are weighted together. An aggregation, however, begins on the factual level. If I, for example, were going to buy a car and the objective was to buy a car that was economic and safe, repair and insurance costs, taxes and fuel consumption would be important economic factors. These costs can be determined for different car models and they therefore constitute concrete factors at the bottom of a decision tree. The same applies for safety. Data on safety can be obtained from crash test findings. Data is also available on the active and passive safety of various models. For each objective, there are now a number of concrete factors and these should be weighted together. So what is the next step? Should the factors favouring economy and those favouring safety be weighted against each other? Or should they be weighted together? Because I want the model I choose to be good in terms of both economy and safety, it could first appear that economy should not be weighted against safety. Yet, at the same time, there are two objectives that should somehow be weighted together. But it is not certain that I value the factors that favour economy as much as those that favour safety.

According to MCA, a weighting is done in the overall assessment by giving different weight to different factors for economy and safety. ${ }^{93}$ When MCA is used, it thus does not become evident if it is a matter of balancing of interests or overall assessment, but rather this question comes into play when - after the analysis - a decision should be made. In addition, whether I call the car purchase the result of a balancing of interests or an overall assessment, I may choose the same model of car. If, however, the car's safety were to be a prioritized interest, corresponding to an interest protected by law, the compared safety factors of the cars will be accorded relatively more weight than other factors and in any case, when the final position is taken, the prioritized interest will tip the balance between the competing car models if they are otherwise equivalent. In an overall assessment, the car that received the highest points in all factors would instead be the winner if there was no prioritized interest. For this reason, a balancing of interests concerning a legally protected interest should therefore be seen as a decision rule. Thus, overall assessments and balancing of interests can then be performed with the same model, but the decision or judgement and the direction it goes can be influenced by whether it is an

93 See section 2.3.5 below for further discussion on this. 
issue of a legal or law-based balancing of interests or a 'neutral' overall assessment.

An overall assessment thus concerns factors, while a balancing of interests relates specifically to interests. If it is stipulated by law that a balancing of interests must be done, the objective is to channel factors to the stated interests; this is the weighing pan. In addition, in an overall assessment a factor does not generally have a particular weight from the start. $^{94}$ Furthermore, and as shown above, there could very well be a difference with respect to the outcome if the law prescribes a balancing of interests instead of an overall assessment, albeit this conclusion at a first glance might be deemed as somewhat tempered by precedent (NJA 2008 p. 55 and NJA 2013 p.441) and the reasons given for video conferencing and the taking of evidence/testimony cited above. One hypothesis is that this can be due to the balancing of interests concerning more than two interests. If the balance scale metaphor is to be used in such cases, it seems clear that it can be unimportant whether we are talking about a balancing of interests or an overall assessment. If there are several interests, these must ultimately either be weighted together through an overall assessment or else several interests be combined, if this is possible, into two interests so as to facilitate the use of the balance scale as a substantive decision rule, which would seem to be necessary if this concerns a law-based balancing of protected interests. Another explanation for inconsistencies is that the terms balancing of interests and overall assessment are used synonymously without further reflection. Presumably, this happens sometimes and perhaps even often.

\subsubsection{The Principle of Proportionality, 'Special Reasons' and Other Markers}

The balance scale metaphor suggests the notion that a weighting is mechanical; factors that speak for or against something are placed in each weighing pan. The decision-maker then reads the scale - quite simply looks to see if the advantages of an action are heavier than the disadvantages and then makes a decision. Figure 1.1 below illustrates that circumstances and aspects are sorted in under public and private interests which are weighted against each other. On the top of the decision tree, an overall assessment is made in order to fine-tune the balancing.

However, the principle of proportionality (for example, under the Environmental Code), makes the balancing of interests more complicated.

94 An exception is the abovementioned 6:2a FB, where particular importance should be attached to certain risks. 


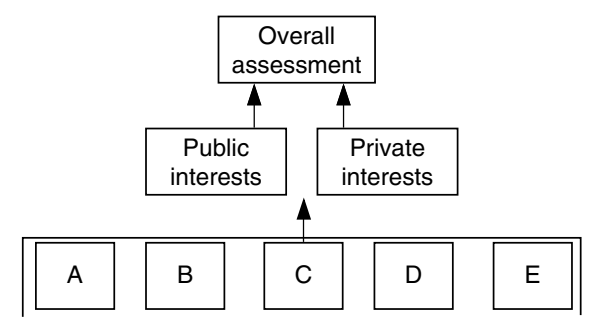

Figure 1.1 Balance of interests

In addition, there are prerequisites with different contents relating to the weighting. Thus, exemption from protection pursuant to the Environmental Code requires 'special reasons'. Another example is, as mentioned above, that duty to disclose trade secrets requires 'extraordinary cause'. For duty of disclosure, it means that it may not be enough that there are sufficient grounds for the document to be produced and that the scale tips slightly in favour of the party petitioning for disclosure; the weighting must be significantly in favour of the petitioner. Weights can also be found in overall assessments; for example, special consideration must be given to ensuring that the child is not 'mistreated'. This weighting is, however, not general but instead refers to a preselected factor that must, when there are reasons, be included in the overall assessment.

The principle of proportionality exists on different levels: between states, groups or individuals or in the state against the individual. In principle, if there is a right that is considered fundamental, usually a constitutional right, and this right is restricted in some way, there must be 'special reasons' or similar for such a measure. The worth of the right or interest in upholding it will then be weighed against an opposing interest. In European Union law, a proportionality test must be done, consisting of three criteria that must all be met for a measure to be considered proportional. These are: is the measure suitable to achieve a legitimate aim? Is the measure necessary to achieve that objective or are less restrictive means available? Is the utility the measure provides in reasonable proportion to the harm that the measure can cause for those involved? Measures must not exceed that which is necessary with regard to the aim, for example society's requirements for safety against the individual's right to privacy. The principle of proportionality is thus also a principle of law and order, in that it means that there must be a balance between the ends and the means. ${ }^{95}$

95 Regarding balancing of interests in EU law, see TJFF 2012, 5th booklet. 
Westerlund argues that there is not only one, but rather three principles of proportionality in the Environmental Code. One concerns the political proportionality assessment. As I interpret his argument, this is about the deliberations conducted when certain legislation is introduced. The second is about the substantive proportionality assessment that is done in this specific case. The third, which Westerlund calls instrumental, is used, he says, to assess how already established goals and objectives should be achieved in the least intrusive manner. ${ }^{96}$

According to Westberg, a proportionality assessment generally means that a risk assessment and a risk distribution must be performed. He says that one of the parties in an uncertain decision-making situation must bear the risk for the damages that can arise as a result of a decision. ${ }^{97}$ This formulation is reminiscent of a burden of proof rule, yet the principle of proportionality is not considered to be a burden of proof rule and Westberg does not claim this, not even mentioning burden of proof rules in this context. However, if Westberg is right in that one of the parties in an uncertain decision-making situation must bear the risk for the damages that can arise, it seems like the principle of proportionality also could function as a burden of proof rule. One objection could possibly be that the principle of proportionality is a substantive rule. The burden of proof rules are, however, also considered to be substantive..$^{98}$ If both the burden of proof rules and the principle of proportionality are substantive, wherein lies the difference? It could be argued that the burden of proof rules concern uncertainty regarding factual elements in the case while the principle of proportionality concerns a weighting between opposing substantive interests. In this case, the burden of proof rules are substantive in a different way than the principle of proportionality; the former are substantive as a counterpart to the substantive regulation in question, because the assignment of the burden of proof must be based on this. From this aspect, the burden of proof issue is already settled when the proportionality issue is assessed. The proportionality assessment thus becomes a substantive weighting issue. This can be an important difference, but the distinction does not seem entirely convincing. It is in any case difficult to see how the boundaries between the burden of proof and the proportionality test could be more specifically defined.

The principle of proportionality finds expression in many rules of law.

96 Staffan Westerlund, Proportionalitetsprincipen: verklighet, missförstånd eller nydaning (1996) Miljörättslig tidskrift (2) 254.

97 Westberg (n 46) 194.

98 Lars Welamson and Johan Munck, Processen i hovrätt och Högsta domstolen (4th edn, Norstedts Juridik 2011) 115. 
Shoreline protection in accordance with 7:25 MB was previously used as an example of balancing of interests. The shoreline protection entails a restriction of the individual's right to have free recourse to his or her property, a right that is prescribed in 2:18 RF. Because exemption is required to build in shoreline-protected areas pursuant to $6: 18 \mathrm{MB}$, conservation and environmental interests in the law are given precedence over the individual interest in using the shoreline-protected area. ${ }^{99}$ It is this initial balancing of interests that Westerlund calls political. MB lists the factors that may be considered 'special reasons' for exemption from the prohibition against building on shoreline-protected areas. According to a ruling by the Land and Environment Court, exemption cannot be granted for factors other than those listed in MB 7:18 c-d. ${ }^{100}$ It is therefore a legal balancing of interests. ${ }^{101}$ If 'special reasons' in the case do not exist, exemption may not be granted with reference to the principle of proportionality. What significance does the principle of proportionality have, then? If there are 'special reasons', the principle has no significance at all. An approval means of course no further restriction on the individual's rights. On the other hand, an approval means a restriction on public interest, which is, however, already protected in the law through the requirement on exemption. ${ }^{102}$ It is thus not possible, after conditions for exemption are found, to give a refusal with reference to the principle of proportionality, just as exemption cannot be granted with reference to the principle of proportionality after it is established that there are no grounds for exemption. It would seem, in view of the foregoing, that the principle of proportionality could be used in borderline cases in favour of the property owner, that is, if it is uncertain if there are legal grounds for exemption.

If a property owner wants to build a pier in the shoreline-protected area, exemption may be granted if its function requires that it must be located at the water and the construction cannot be built outside the area. If the property owner claims he must be able to dock at his property from the water and the area is inhospitable and not used by the public, and the alternative for the property owner would be to travel 100 kilometres by car instead of 200 meters by boat, it can still be said that the pier is not needed, but at the same time a refusal with reference to these factors would seem disproportionately severe against the property owner. Furthermore,

99 See cabinet minister's statement in Government Bill 1997/98:45, Part 1, 321.

100 MÖD M 5451-13.

101 See section 1.3.4 above for a discussion of the difference between law-based and legal-based balancing of interests.

102 Under this notion, the principle of proportionality seems to in this case only go in one direction. 
assume that the property owner has two suggestions for the design of the pier (for the sake of simplicity, we can call the suggestions the 'big pier' and the 'little pier'), and the small pier has less impact on the public interest than the big pier. ${ }^{103}$ It would seem that the proportionality assessment should be made along with balancing of interests and within the list of special reasons provided in the law of situations for which exemption can be granted. However, the principle of proportionality does thereby not become visible in the decision, or at least risks not being. Because the principle of proportionality is a self-contained legal principle, it is obviously desirable that, for reasons of transparency, visibility and clarity, it is made clear in the decision.

For duty of disclosure in the case of documents containing trade secrets, there must be, as mentioned above, 'extraordinary cause'. The implication of this necessary condition is not specifically commented on in case law or the literature. The starting point is that the documents are sufficiently identified and that they can be assumed to have relevance and evidential significance. It would seem reasonable that 'extraordinary cause' means that the information cannot be obtained in another way and that sufficient investigation has been conducted in this regard. The requirements for identification are, however, not set in stone. These requirements can probably be granted a bit of leeway in the balancing of interests.

A trade secret concerns an interest protected by law and hence the high requirements for granting a duty of disclosure. Similar to the example with 'special reasons' for exemption from shoreline protection, the proportionality assessment in this case exists in the legal condition for the right to infringe on the protected interest, that is, in the examination of the prerequisite 'extraordinary cause' in 38:2 RB and in the balancing of interests. Just as in the example with exemption from shoreline protection, the principle of proportionality must be assumed to only work in one direction in this case. Thus, if it is assumed that the very restrictive necessary condition 'extraordinary cause' is met, a proportionality assessment will not be made in respect of the already protected interest to the detriment of the party petitioning for disclosure; if so, it would be practically impossible to be granted disclosure. In other cases (that is, in cases that do not concern trade secrets), the petition for disclosure may, however, be refused because the requested measure is disproportionate to the costs and inconvenience this poses to the other party to produce the documents.

Concerning all coercive measures in criminal procedure, to take a final

103 The size and design of the pier seem to belong to what Westerlund (n 96) calls the instrumental principle of proportionality. 
example, the principle of proportionality is prescribed in RB: the reasons for the measure must counterbalance the infringement or other detriment to the suspect or another opposing interest. The principle of proportionality in detention is established by law in 24:1, paragraph $3 \mathrm{RB}$. In the case of detention, it must first be determined if the necessary conditions for detention are met, that is, that imprisonment for one or more years is prescribed and that one of the grounds for detention have been met. ${ }^{104}$ If the prerequisites are met, detention may be carried out under 24:1, paragraph $1 \mathrm{RB}$. Detention is thus not mandatory under this provision, nor is there a presumption of detention as in the second paragraph. One might think that the optional provision provides for a proportionality assessment, but this is, as discussed, specifically regulated in paragraph 3 .

The interests that are in conflict with each other in the case of detention under RB 24:1, paragraph 1 are the individual's interest in not being deprived of liberty and the public interest in preventing new crime, impeding the suspect from fleeing and in being able to prosecute without important evidence being tampered with or destroyed. When the balancing of interests is formulated in this way, without concretion, it is initial. If advanced age and failing health are invoked as reasons against detention, and if the crime is just over the minimum of one year in the range of punishment and the crime was provoked, these circumstances may be weighted together after an overall assessment and then form the basis for the balancing of interests. The prosecutor can then plead, for example, that the crime concerned violence against an official, a serious classified crime. It then becomes clear that in the end, a combined weighting of the factors must be done from various perspectives, and that the initial assessment must be moved to another level where an overall assessment is made along with the balancing of interests, and finally, on top to fine-tune the assessment.

\subsection{SUMMARY AND CONCLUSIONS}

From this chapter, it is clear that the book is about a structured way of making overall assessments and balancing of interests. Various decision theory premises and classifications have been presented. The simple additive model has been selected as a model for the forthcoming analyses.

104 These conditions are that the suspected person will: (1) flee or otherwise evade legal proceedings or punishment; (2) impede the inquiry into the matter at issue by removing evidence or in another way; or (3) continue his criminal activity. 
An overall assessment means that a choice must be made between several possible decision options using certain criteria in order to achieve one or more objectives. Balancing of interests also involves multiple options, criteria and objectives. In this chapter, it has been examined whether there is any difference between overall assessments and balancing of interests, and if so, what that difference may be. It is not an easy task to examine this question, but the same structured decision support can be used for both. There is, however, one important difference. A law-based balancing of interests is not just a weighting. It also functions as a decision rule or at least as a part of a decision rule. Substantive markers, such as 'special reasons' or 'extraordinary cause' mean that the scale is out of balance at the onset. In the example of shoreline protection, the public interest outweighs the private interest right from the start. Let us say that it weighs $15 \mathrm{~kg}$ and the private interest weighs $10 \mathrm{~kg}$. The property owner must therefore not only add special reasons weighing $5 \mathrm{~kg}$ to put the scale in balance, but rather must add $30 \mathrm{~kg}$ or maybe more in order to get an exemption. The balance scale metaphor illustrates what I call a vertical decision-making situation. The overall assessment, on the other hand, is horizontal, that is, flat. For example, the plaintiff alleges five circumstances, legal facts (criteria) to support the argument that the agreement is 'unreasonable'. Let us say that these weigh 10, 15, 9, 7 and 6 kilos. These are not placed in any weighing pan because no interest has been designated priority from the start. Consequently, this is not a situation where different interests are balanced against each other. The decision-maker can therefore not use a balance scale as decision support. It may therefore be significant to the decision's contents if an overall assessment is made or a balancing of interests is done.

Another question is whether Odelstad is right in that a total appraisal (overall assessment) is also done in a balancing of interests. In complicated balancing of interests, a total appraisal is probably made at the end, which also seems consistent with common practice. Even if such an overall assessment is made, this does not change the fact that this basically concerns a weighting in law-based balancing of interests and that the balancing of interests is primary because it functions as a decision rule or as a key element in a decision rule. The overall assessment that is made, where appropriate, in the balancing of interests, should therefore be regarded as a final check of the balancing that has been done.

Overall assessments may need to be done on several levels leading up to the total appraisal. In simpler cases, the decision-maker does not need to make this total and final appraisal because it becomes clear on a lower level which decision will be made. This also means that the principle of proportionality sometimes is not relevant or that it is clear that there are 
not 'special reasons' or 'extraordinary cause' or similar. Another question which has been discussed in this chapter is whether there is any space for public interests when two private interests are in conflict with each other in a dispute amenable to out-of-court settlement. If there are no law-based interests involved, it has been argued that the weighting should only concern the parties' interests. If law-based interests are involved in a dispute amenable to out-of-court settlement, the assessment becomes more complicated. 